\title{
Bio-ethanol production from Jatropha curcus
}

\author{
S.M.A. Sujan ${ }^{1,2 *}$, M. S. Jamal ${ }^{2,3}$, M. A. Asad ${ }^{2}$ and A. N. M. Fakhruddin ${ }^{1}$ \\ ${ }^{1}$ Department of Environmental Science, Jahangirnagar University, Dhaka-1342, Bangladesh \\ ${ }^{2}$ Institute of Fuel Research and Development (IFRD), BCSIR, Dhaka-1205, Bangladesh \\ ${ }^{3}$ Solar Energy Research Institute (SERI), UKM, Bangi, 43600, Selangor, Malaysia
}

Received: 23 March 2018

Revised: 16 April 2018

Accepted: 23 May 2018

DOI: https://doi.org/10.3329/bjsir.v54i1.40729

\begin{abstract}
Separate hydrolysis and fermentation (SHF) were employed to produce bio-ethanol from the jatropha stem and husk. This study investigates the favorable condition required to improve yield of monomeric sugars. Substrate was pretreated physically at first through cutter mill and subsequently by ball milling. Acremonium cellulase and optimash BG hydrolyzed the pretreated sample into fermentable sugars. In condition of $10 \%$ substrate concentration, ball milling for $60 \mathrm{~min}$ and $4 \mathrm{FPU} / \mathrm{g}$ enzyme loading and optimum sugar yield were observed. By comparison, jatropha stem is more favorable feedstock compared to jatropha husk in terms of both inherent sugar composition and sugar yield in enzymatic saccharification (hydrolysis). Yeast Saccharomyces cerevisiae, capable of converting hexose sugars into ethanol,was utilized in fermentation step. It was possible to extract $0.14 \mathrm{~L}$ and $0.20 \mathrm{~L}$ of ethanol per $\mathrm{kg}$ of dry substrate-based jatropha husk and jatropha stem, respectively.
\end{abstract}

Keywords: Enzymatic saccharification; Fermentation; Lignocellulosic biomass; Monomeric sugar; Physical pretreatment

\section{Introduction}

Depletion of world's energy resources based on non-renewable fuels has forced to switch our focus on alternative sources of energy. Biomass energy can be a good candidate in compensating this energy crisis. It is estimated that biomass would complement solar, wind and other form of intermittent energy sources in future renewable energy sector. About $200 ? 10^{9}$ tons of plant biomass, of which $90 \%$ is lignocellulose, is being produced worldwide per year (Lin and Tanaka, 2006). This vast amount of biomass can be utilized as renewable energy sources.

Bio-ethanol is the most important product derived from biomass in terms of volume and market values (Taherzadeh and Karimi, 2007). Although use of food crop in bio-ethanol production contributes in global food shortages and price hike, this predicament can be eliminated largely through exploitation of non-food (non-edible) crops and biomass residues. Process based on consequent enzymatic saccharification (hydrolysis) and fermentation is considered now as a promising method of converting the lignocellulosic carbohydrates into ethanol with high yields and low production cost (Sassner et al., 2006). Enzymatic hydrolysis can be carried out in mild conditions (at $\mathrm{pH} 4.8$ and 45-50 ${ }^{\circ} \mathrm{C}$ ), which minimizes utility cost and offers no corrosion problem. High yield, sometimes close to $100 \%$, and no formation of inhibitory by-products make enzymatic hydrolysis attractive compared to acid or alkaline hydrolysis. In contrast, the drawbacks in this mode of hydrolysis are long time hydrolysis process and relatively high cost of enzyme (Balat et al., 2008; Taherzadeh and Karimi, 2007).

In separate hydrolysis and fermentation (SHF) process, pretreated lignocellulosic materials first undergo hydrolysis by enzymes. These are degraded to monomeric sugars. Thereafter, these sugars are fermented to ethanol in a separate unit. The prime advantage of this process is that each step (saccharification and fermentation) can be performed at its optimal operating conditions (Sanchez and Cardona, 2008). 
Fermentation process can also be carried out in a continuous mode with yeast recirculation. This is made possible since lignin residue removal may occur prior to fermentation (Galbe et al., 2005). Risk of contamination (Taherzadeh and Karimi, 2007) inhibitory effect of process end products (glucose and cellobiose) (Alfani et al., 2000)and overall high capital cost sometimes impede SHF to be utilized on industrial scale.

Lignin mainly interferes with the enzymatic hydrolysis of lignocellulosic biomass (Karki et al., 2011). Alongside lignin, hemicellulose also impedes (makes) the access of cellulase enzymes to cellulose difficult. Different physical, physico-chemical and chemical pretreatments aid to improve the efficiency of hydrolysis through removing lignin and hemicellulose, reducing cellulose crystallinity, and increasing available surface area and pore volume of the substrate (Alvira et al., 2010; Sun et al., 2002). Pretreatment is considered as an expensive processing step in bio-ethanol production. Introduction of cost-effective pretreatment process is of great importance in cellulose to ethanol technology (Chan et al., 2007).

Physical pretreatment like ball milling at various conditions is responsible for effectively reduce in cellulose crystallinity of any lignocellulosic waste biomass and improve enzyme digestibility (Teramoto etal., 2008; Mais et al., 2002; Jamal et al., 2011). Bioethanol production from various biomass with different physical pretreatments were practiced all over the world. In this consequence, ball milling pretreatment technique was employed to enhance saccharification and fermentation process and finally ethanol production from sugarcane bagasse (Jamal et al., 2011; da Silva et al., 2010), corn stover (Lin et al., 2010), straw (da Silva et al., 2010), Eucalyptus (Inoue et al., 2008) etc.

Jatropha, mostly a tropical plant, produces fruit containing $37.5 \%$ shell and $62.5 \%$ seed on dry basis. Kernel occupies $58 \%$ portion of seed and the remaining is mainly hull/husk. Through mechanical extraction, $28-29 \%$ oil can be recovered from seed which on fruit weight basis is only $17-18 \%$. This oil is non-edible in nature and can be converted into bio-ethanol with about $95-97 \%$ yield. While this oil is exclusively employed in bio-ethanol production, utilization of other parts of plant or fruit for this purpose was not given much attention (Singh et al., 2008). Largeunused area of about 0.32 million hectare prevails in Bangladesh that can be utilized in Jatropha plantation. The agro-climatic condition prevailing in Bangladesh is also suitable for Jatropha cultivation. On average 2,500 jatropha tree can be planted in one hectare area (Nabi et al., 2009). On using bio-ethanol from Jatropha plants, Bangladesh can reduce its dependency on import of petroleum oil.

This studyinvestigates the utilization of different parts of jatropha plants other than seed, as potential source of bio-ethanol production through SHF method. In this context, evaluation of effectiveness of physical pretreatment method and process optimization in enzymatic saccharification are conducted. This study also focuses on the maximum ethanol yield achievable from this raw material.

\section{Materials and methods}

\section{Materials}

Different parts of jatropha plant (Jatropha curcas) were used in this study. Jatropha stem (maturity of 12 years) and jatropha husk (fruit shell) were obtained from research filed of Bangladesh Council of Scientific and Industrial Research (BCSIR). The pictorial display of these materials is shown in Fig1. After collection, jatropha stem was chopped and sun dried. Sun drying was also performed in case of jatropha husk. Before pretreatment, all materialswere oven dried at $60^{\circ} \mathrm{C}$ for three days.

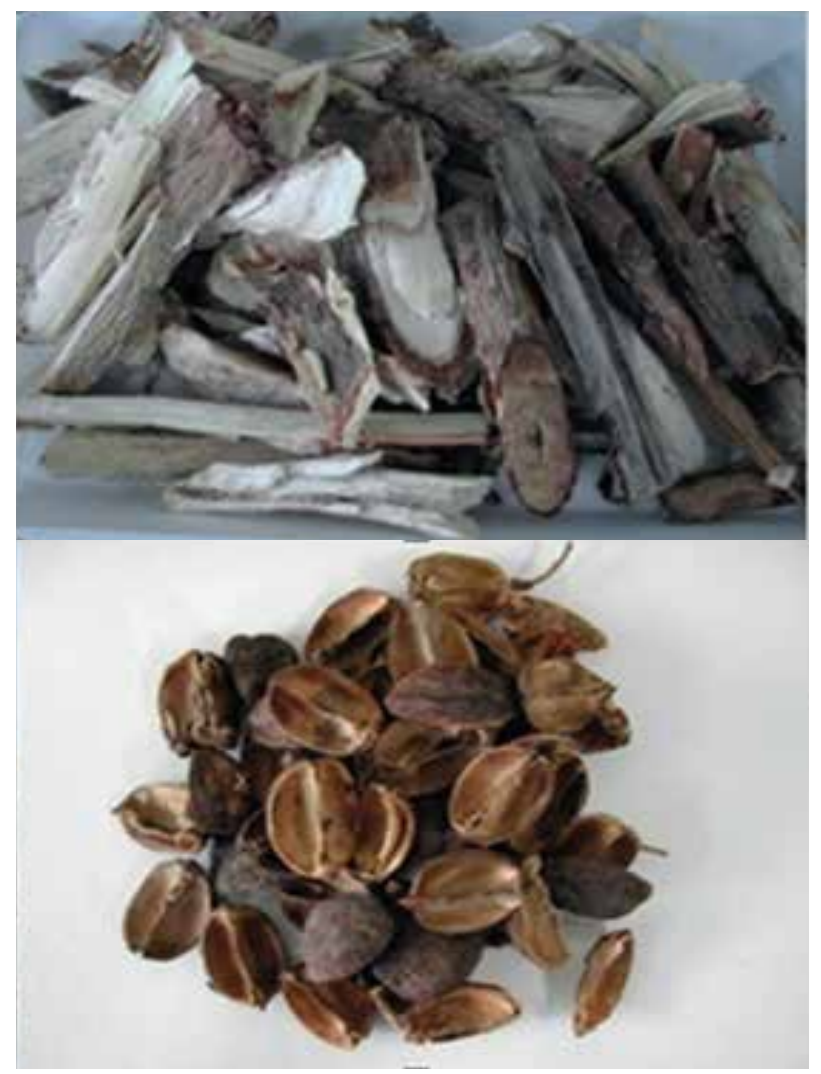

Fig. 1. Photograph of (a) jatropha stem and (b) jatropha husk 


\section{Pretreatment}

Dried raw materials (jatropha wastes) were first treated by cutter mill (Fritsch, Germany) whereby their size was reduced into $2 \mathrm{~mm}$ (MM-2) and $0.2 \mathrm{~mm}$ (MM-0.2). Raw materials with $2 \mathrm{~mm}$ size were then subjected to ball milling (TI-300, CMT Co., Saitama, Japan) and those of $0.2 \mathrm{~mm}$ size were used in acid hydrolysis for determining sugar composition. In ball milling operation, raw materials were pretreated with ball for $10 \mathrm{~min}$ (MC-10), $30 \mathrm{~min}$ (MC-30), 60 min (MC-60) and $120 \mathrm{~min}$ (MC-120) at room temperature. The particle size of raw materials was reduced upto $20 \mu \mathrm{m}$ during ball milling.

\section{Analyses of chemical composition}

\section{Moisture and ash content}

ASTM D 4442-07 was used to determine the moisture content of raw materials. About two grams of pretreated samples (ball milled for $60 \mathrm{~min}$ ) were taken in a glass crucible and oven-dried at $105 \pm 2{ }^{\circ} \mathrm{C}$. Weight measurement was carried out in a 3 hours interval and moisture content was expressed in percent wet basis. To determine ash content, over-dried samples were heated in a muffle furnace at $575 \pm$ $25^{\circ} \mathrm{C}$ according to ASTM Standard E 1755-01. Ash content was expressed as a percentage of sample's oven-dried weight.

\section{Sugar composition}

Sugar composition of substrate (ball milled raw materials) was analyzed according to the procedure proposed by National Renewable Energy Laboratory (NREL) (Sluiter et al., 2008). According to this method, $0.3 \mathrm{ml}$ of $72 \% \mathrm{H}_{2} \mathrm{SO}_{4}$ has been added to hydrolyze the substrate in order to release monomeric sugars into the liquid fraction and 1\% sugar (glucose, xylose, galactose, arabinose and mannose) solution is used as standard. Monomeric sugars in the hydrolysate were then analyzed by HPLC (column temp: $80{ }^{\circ} \mathrm{C}$, column: Biorad Aminex HPX-87P; 300 ? $7.8 \mathrm{~mm}$, stationary phase: lead ionic form supported on sulfonated divinyl benzene-styrene copolymer, mobile phase: degassed deionized water, flow rate: $1.0 \mathrm{ml} / \mathrm{min}$, pressure: $10342 \mathrm{kPa}$, refractive index detector, Jasco, Japan).

\section{Yeast inoculum preparation}

Yeast strain Saccharomyces cerevisiae, also known as $\mathrm{IR}_{2}$ was used to ferment sugars derived from enzymatic saccharification (Kuriyama et al., 1985). Only hexose sugars can be converted into ethanol by this fermenting organism strain (Palmqvist et al., 1996). Before inoculation, the yeast strain was isolated in a medium composed of glucose, peptone, yeast extract and agar (Difco). Yeast cell preculture, also known as YPD preculture was carried out in a $250 \mathrm{ml}$
Erlenmeyer flask containing $60 \mathrm{ml}$ culture medium containing $0.1 \%(\mathrm{w} / \mathrm{v})$ yeast extract and $0.2 \%(\mathrm{w} / \mathrm{v})$ peptone supplemented with $2 \%(\mathrm{w} / \mathrm{v})$ glucose. The flask was kept at $30^{\circ} \mathrm{C}$ overnight in a non-gassed (microbiological) incubator and stirring was continued at that period. After cultivation, the yeast cells were separated from liquid medium by centrifuge at $10,000 \mathrm{rpm}$ for 5 minutes. To utilize it in fermentation, yeast cells were washed with $0.9 \%$ sodium chloride and then dispersed into $0.9 \%$ sodium chloride solution by gentle shaking. Through this culture, the initial cell concentration i.e $\mathrm{OD}_{600}$ was found $5-10$ cells $/ \mathrm{ml}$.

\section{Separate hydrolysis and fermentation (SHF)}

\section{Enzymatic saccharification}

Enzymatic saccharification (hydrolysis) was carried out to recover fermentable monomeric sugars (mainly glucose and xylose) from pretreated raw materials. The standard enzymatic saccharification reaction mixture consists of 80 FPU/ml enzyme acremonium cellulase and 10\% optimash BG. Initially sample of zero hour of hydrolysis was taken for analysis. Hydrolysis was then performed in $50 \mathrm{mM}$ acetate buffer ( $\mathrm{pH} 5.0$ ) at $50^{\circ} \mathrm{C}$ for 72 hours with continuous stirring. A portion of the hydrolysis product (usually $0.5 \mathrm{ml}$ ) of 3,6 , 24, 48 and 72 hours were removed periodically to determine sugar yield.

In this study, optimal substrate concentration was initially selected where MC-60 sample was saccharified with 4 FPU/g of dry substrate enzyme load and 5-15\% substrate concentration. The effects of pretreatment type and time on enzymatic saccharification were then studied in which samples from different pretreatment conditions were hydrolyzed with the optimum substrate concentration and enzyme load of $4 \mathrm{FPU} / \mathrm{g}$. Finally, the effects of different enzymatic loadings on saccharification process were considered by using favorable condition of pretreatment and substrate concentration. For this, a number of different enzyme loads per gram of substrate, such as $4 \mathrm{FPU} / \mathrm{g}, 8$ FPU/g, 12 FPU/g and $20 \mathrm{FPU} / \mathrm{g}$ were used.

\section{Adjustment of hydrolysate sample for fermentation}

The $\mathrm{pH}$ of hydrolysate prepared through enzymatic saccharification for 72 hours was then adjusted before inoculation with yeast cells. For this purpose, $\mathrm{NaOH}$ was used to maintain $\mathrm{pH}$ at 6.0 . The volume of hydrolysate was also adjusted by adding sterile water.

\section{Fermentation}

The $\mathrm{pH}$ adjusted hydrolysate was inoculated with $2 \mathrm{ml}$ of YPD preculture of Saccharomyces cerevisiae $\left(\mathrm{IR}_{2}\right)$ in Fermentation vial (Aspect ratio: 8-10; Hydrolysis volume: 30 
$\mathrm{ml})$. After inoculation, $1 \mathrm{ml}$ fermentation mixture of zero hour of fermentation was removed for analysis. Fermentation was then carried out at $30^{\circ} \mathrm{C}$ for 72 hours under incubation and constant stirring at $35 \mathrm{rpm} .1 \mathrm{ml}$ solution each from 3, 6, 24, 48 and 72 hours of fermentation mixtures were taken out to determine ethanol production. Since increase of both substrate concentration and enzyme loading contributes in sugar yield augmentation, to obtain the highest amount of ethanol from jatropha waste, fermentation was performed with hydrolysate acquired through enzymatically hydrolyze MC-60 sample in condition of $15 \%$ substrate concentration and $20 \mathrm{FPU} / \mathrm{gm}$ enzyme loading. The process flow diagram for ethanol production from jatropha waste is shown in Fig. 2.
Where, $E$ is the ethanol concentration in fermentation mixture, $S$ is initial glucose concentration, $W$ is dry substrate weight, and $V_{f}$ and $V_{s}$ denote the initial volume of fermentation and final volume of saccharification respectively. Besides, 0.79 is the density of ethanol in $\mathrm{g} / \mathrm{ml}$ and 0.514 is theoretical ethanol conversion from glucose.

\section{Results and discussion}

\section{Chemical composition of substrate}

In chemical composition analysis, sugars content, moisture and ash content of substrate were studied. The

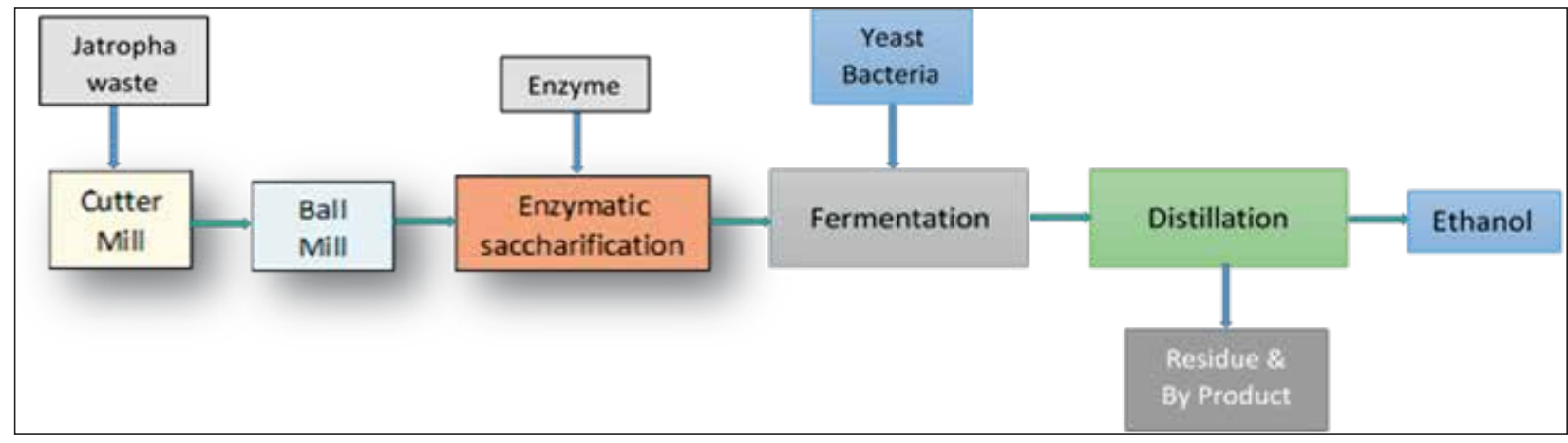

Fig. 2. Process-flow diagram for ethanol production from jatropha waste

Analysis of hydrolysate and fermentation products

Analysis of sugar mixture from enzymatic saccharification and ethanol production through fermentation was performed by HPLC using Aminex HPX-87P column and refractive index detector. Other specifications are identical with that used for substrate composition analysis obtained through acid hydrolysis.

Sugar yield in the liquid fraction of hydrolyzed substrate was determined by comparing its peak area detected by HPLC with that of $1 \%$ standard sugar solution. Theoretical yield of sugar was calculated on the basis of sugar yield obtained from acid hydrolysis.

Theoretical yield $(\%)=[$ Experimental yield $/$ Yield by acid hydrolysis] x 100

Ethanol yield was calculated both as percentage basis by comparing to its theoretical ethanol conversion, and as liter of ethanol per kg of dry substrate basis.

Ethanol yield $(\%)=[(E \times 0.79) /(S \times 0.514)] \times 100$

Ethanol yield (liter $/ \mathrm{kg}$ of substrate $)=\left[\left(E_{\mathrm{x}} V_{f}\right) /\left(V_{S} \mathrm{x} W\right)\right]$ composition of jatropha stem and husk is shown in Table I. Glucose content was the higherin jatropha stem (40.5\%) which is followed by jatropha husk (29.5\%). In case of xylose content, jatropha stem also contains higher percentage of xylose $(16.18 \%)$, followed by jatropha husk $(9.34 \%)$. Other sugars namely galactose, arabinose and mannose are present in low amount (less than 3\%). Moisture and ash content are higherin case of jatropha stem (3.65\%) and jatropha husk $(17.3 \%)$ respectively.

\section{Enzymatic saccharification}

\section{Optimization of substrate concentration}

To obtain the optimal substrate concentration, jatropha waste pretreated for 60 min was enzymatically hydrolyzed with 5,10 and $15 \%$ substrate concentration using the same enzyme loading i.e., $4 \mathrm{FPU} / \mathrm{g}$ of dry substrate and the results are presented in Table II. In case of both jatropha husk and stem, glucose and xylose composition decreased with subsequent increase in substrate concentration but overall yield of fermentable sugars increased. With regard to jatropha waste, xylose composition reduced rather slowly compared to glucose content. Although 
Table I. Composition of jatropha waste expressed as \% of dry matter

\begin{tabular}{llllllll}
\hline Substrate & $\begin{array}{l}\text { Glucose } \\
(\%)\end{array}$ & $\begin{array}{l}\text { Xylose } \\
(\%)\end{array}$ & $\begin{array}{l}\text { Galactose } \\
(\%)\end{array}$ & $\begin{array}{l}\text { Arabinose } \\
(\%)\end{array}$ & $\begin{array}{l}\text { Mannose } \\
(\%)\end{array}$ & $\begin{array}{l}\text { Moisture } \\
(\%)\end{array}$ & $\begin{array}{l}\text { Ash } \\
(\%)\end{array}$ \\
\hline Jatropha husk & 29.5 & 9.34 & 2.04 & 0.82 & 2.41 & 3.31 & 17.3 \\
Jatropha stem & 40.5 & 16.2 & 2.23 & 0.16 & 1.02 & 3.65 & 5.86 \\
\hline
\end{tabular}

enzymatic activity changes in direct proportion with enzyme concentration, it becomes limiting at higher substrate concentration due to deficiency of active sites on enzyme. This low enzymatic activity at higher substrate concentration
Effect of pretreatment process on glucose and Xylose yield At $10 \%$ substrate concentration and $4 \mathrm{FPU} / \mathrm{g}$ enzyme load, yield of glucose and xylose from jatropha husk and jatropha stem through enzymatic hydrolysis increased with extension

\section{Table II. Variation of sugar yield with substrate concentration}

\begin{tabular}{|c|c|c|c|c|}
\hline \multirow[t]{2}{*}{ Substrate } & \multirow[t]{2}{*}{ Sugar } & \multicolumn{3}{|c|}{ Sugar composition (\%) at substrate concentration } \\
\hline & & $5 \%$ & $10 \%$ & $15 \%$ \\
\hline \multirow[t]{2}{*}{ Jatropha husk } & Glucose & 82.37 & 77.10 & 67.18 \\
\hline & Xylose & 53.20 & 50.49 & 43.27 \\
\hline \multirow[t]{2}{*}{ Jatropha stem } & Glucose & 83.69 & 80.73 & 75.45 \\
\hline & Xylose & 51.32 & 48.68 & 44.76 \\
\hline
\end{tabular}

primarily contributes to reduction in hydrolysate sugar composition. Alternatively, high substrate loading is necessary to increase sugar yield and economize cellulosic ethanol production (Ong et al., 2012). Taking these factors into consideration, 10\% substrate concentration is chosen as optimum condition for succeeding experiments. During hydrolysis, arising mixing difficulties and accumulation of inhibitors in reaction medium also make $10 \%$ solid concentration the most adequate one (Sanchez and Cardona, 2008). of pretreatment time (in Fig. 3(a) and 3(b). Such physical pretreatment enhances effective surface area to enzymes by unfolding lignocellulosic constituents and it adds no additional value to raw materials (Duff et al., 1996). With reference to the data presented in Figure 3(a), rapid increase in glucose concentration was observed between ball milling time of 30 and $60 \mathrm{~min}$ and improvement of glucose yield becomes insignificant after $60 \mathrm{~min}$.

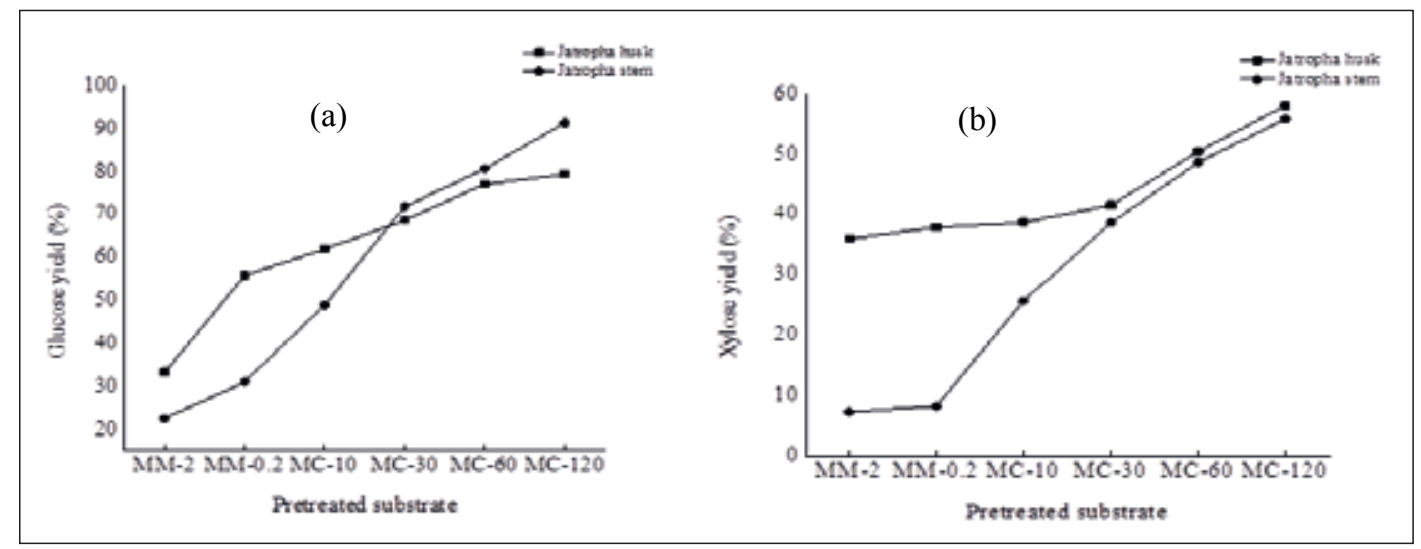

Fig. 3. Yield of (a) glucose (b) xylose from different pretreated jatropha substrate (10\% substrate concentration and 4 FPU/g enzyme load) 
It was also observed that enzymatic digestion was nearly complete in 6 hours for $2 \mathrm{~mm}$ cutter milled sample (MM-2), whereas this process almost came to a halt after 48 hours for other pretreated samples. Raw materials ball milled for $120 \mathrm{~min}$ (MC-120) gave highest glucose yield (79.46\%) after 72 hours. milled for 120 min gave maximum amount of xylose $(55.90 \%)$. Considering the high energy requirement of ball milling pretreatment and corresponding yield of glucose and xylose, pretreatment time of 60 min was selected as optimum situation for both cases and used in subsequent experiments.

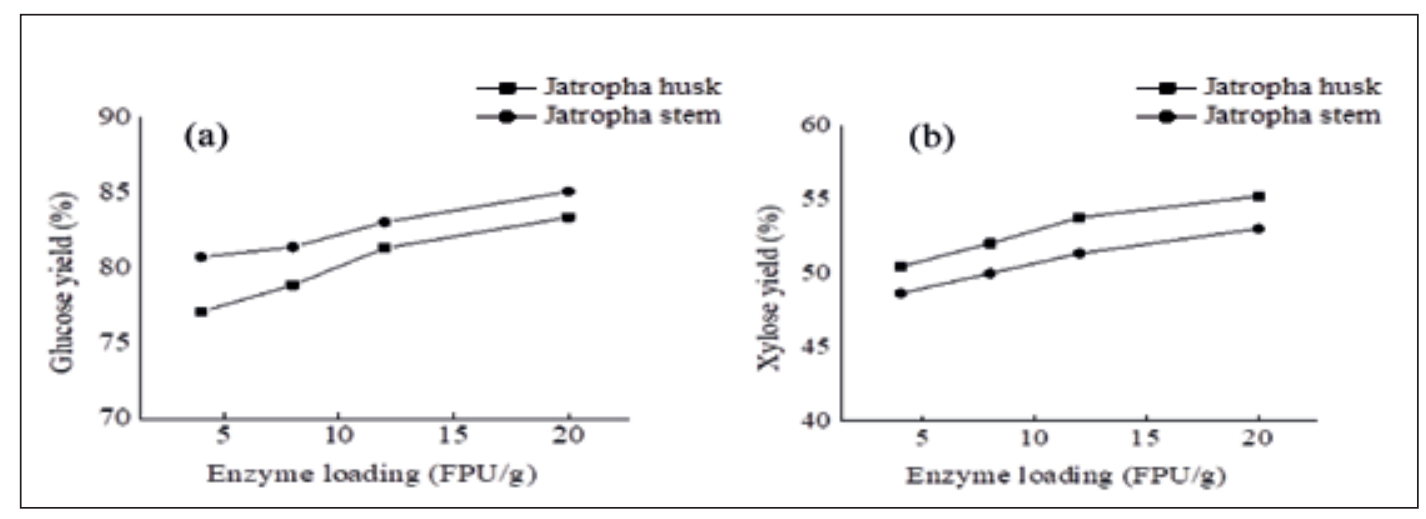

Fig. 4. Effect of enzyme loading on (a) \& (b) glucose and xylose yield (MC-60 and 10\% substrate concentration)

Jatropha stem pretreated by cutter mill are less susceptible to enzymatic saccharification in contrast to jatropha husk under identical conditions (Fig. 3(a)). Here abrupt increase in glucose yield was seen when pretreatment time during ball milling operation exceeded $10 \mathrm{~min}$. In case of cutter milled sample (MM-2 and MM-0.2), glucose concentration decreased after 24 hours of hydrolysis which was followed by a steady increase afterwards. Sample ball milled for $10 \mathrm{~min}$ showed reduction in glucose content after 48 hours. End product (glucose and cellobiose) inhibition, which affects enzyme activity, may be the reason behind this anomaly (Mussatto et al., 2008). In comparison with jatropha husk, jatropha stem ball milled for $30 \mathrm{~min}, 60 \mathrm{~min}$ and $120 \mathrm{~min}$ gave higher glucose yield $(71.96 \%, 80.73 \%$ and $91.96 \%$ respectively) after 72 hours.

Xylose yield obtained from jatropha husk shows similar trend as that of glucose yield except for sample MC-120, in which considerable xylose was produced than preceding pretreated sample (MC-60) as shown in Fig. 3(b). Also, xylose concentration in the hydrolysate increased gradually after 48 hours of enzymatic digestion. Highest xylose content was found in case of ball milled sample of $120 \mathrm{~min}(58.10 \%)$.

Cutter mill pretreatment of jatropha stem gave low xylose yield (around 8.5\%). Xylose concentration increased with ball milled substrate anddifferent ball mill pretreated samples showed large difference in xylose concentration. (Fig. 3 (b). In case of jatropha stem, increase in pretreatment time longer than $10 \mathrm{~min}$ did not give better xylose yield than jatropha husk as was observed regarding glucose yield. Substrate ball

\section{Influence of enzyme load on sugar yield of jatropha waste}

Effect of enzyme load on glucose and xylose yield was studied with substrate pretreated for $60 \mathrm{~min}$ (MC-60) at 10\% substrate concentration. The results are presented in Figs. 4(a) \& (b), respectively. Usually high enzyme loading contributes in enhancing sugar yield (Singh et al., 2008). But in this study, no significant increase in glucose and xylose content was observed on varying enzyme load from $4 \mathrm{FPU} / \mathrm{g}$ to $20 \mathrm{FPU} / \mathrm{g}$. For both the sugars, increase of yield was about $5 \%$. At saturation level of substrate concentration, no additional enzyme activity is observed regardless of augmentation in enzyme load (Yang et al., 2006). Enzyme inactivation due to accumulation of cellobiose may also contribute to small increase in sugar yield (Chen et al., 2008). Since enzyme cost has considerable impact on economics of lignocellulosic bio-ethanol production (Klein-Marcuschamer et al., 2012) enzyme load of $4 \mathrm{FPU} / \mathrm{g}$ is ideal for conducting enzymatic hydrolysis in case of jatropha substrate.

\section{Fermentation}

At hydrolysis condition of $15 \%$ substrate concentration and $20 \mathrm{FPU} / \mathrm{g}$ enzyme loading, pretreated jatropha husk sample MC-60 gave glucose concentration of 3.8\% in hydrolysate after 72 hours. These glucose consumption and ethanol production during the course of fermentation for 72 hours are depicted in Fig. 5(a). Conversion of glucose to ethanol was almost complete within 24 hours. After 72 hours of fermentation, there still remains some glucose (about $0.2 \%$ ) in the fermentation mixture. Oxygen free condition of 


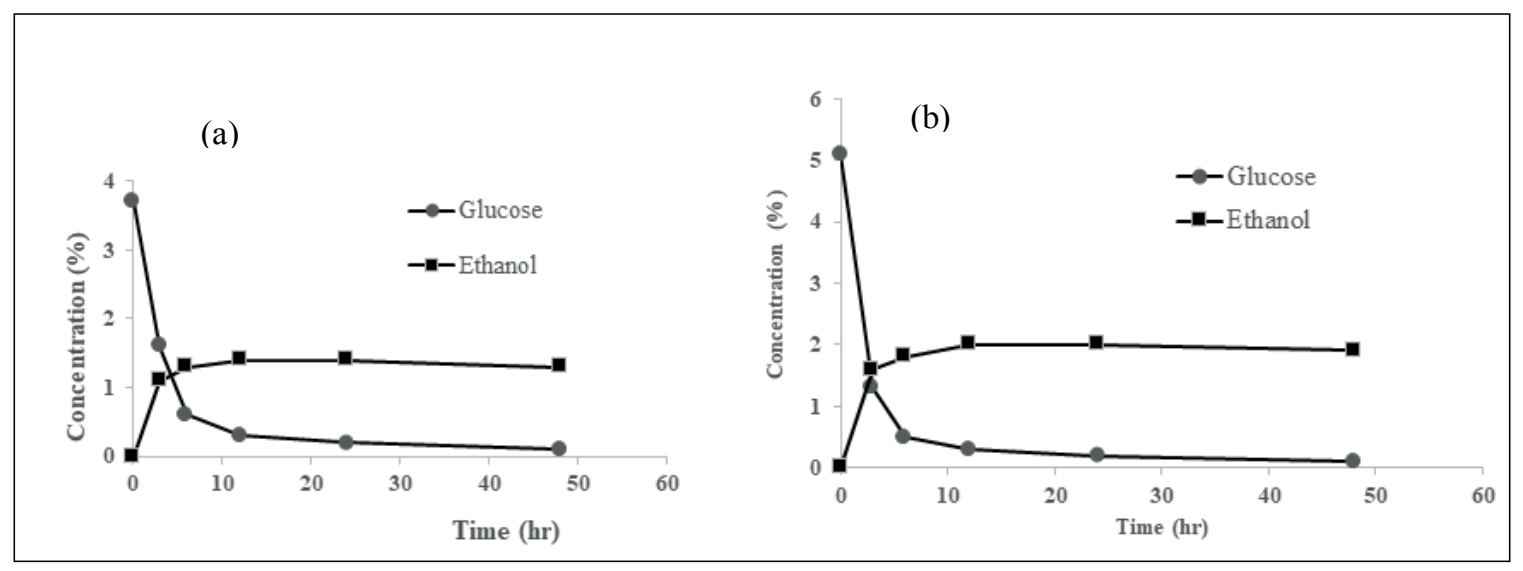

Fig. 5. Conversion of (a) jatropha husk and (b) jatropha stem hydrolysate into ethanol

fermentation slowly annihilates the microorganism population (Lynd, 1996). Furthermore, produced ethanol and some degradation products (furfural, hydroxymethyl furfural and phenolics) arising from pretreatment of lignocellulose inhibit the action of fermenting microorganisms ( $\mathrm{Yu}$ and Zhang, 2003). These eventually give rise to this residual glucose. Ethanol yield of $87.5 \%$ or 0.14 liter $/ \mathrm{kg}$ of ethanol based on dry jatropha husk was achieved.

\section{Conclusion}

This study illustrates that jatropha husk and stem can be considered as a viable bio-ethanol feedstock. Sugar composition analysis showed a higher fraction of glucose and xylose in jatropha stem than husk portion. Low percentage of sugar in jatropha husk may be attributed to its high ash content $(17.3 \%)$. Economic sugar yield has led to the utilization of high substrate concentration (10\%) and low enzyme loading (4 FPU/g).Considerable deviation in glucose and xylose content is observed between cutter mill and ball milling pretreatment. This variation did not follow any definite pattern. Substrate pretreated more than $60 \mathrm{~min}$ has proved to be unnecessary both with respect to required energy and resultant monosaccharide in enzymatic hydrolysis. In fermentation step, complete conversion to ethanol and rapidity of this conversion was also detected in case of jatropha stem hydrolysate. In contrast, alongside fermenting condition, formation of inhibitors due to lack of reaction rapidness inhibits complete conversion of jatropha husk hydrolysate.

\section{Acknowledgement}

Authors would like to acknowledge the support of the JapaneseInternational Cooperation Agency (JCA) and AIST, Japan.

\section{References}

Alfani F, Gallifuoco A, Saporosi A, Spera and Cantarella M (2000), Comparison of SHF and SSF processes for the bioconversion of steam-exploded wheat straw, Journal of Industrial Microbiology \& Biotechnology 25(4): 184-192.

Alvira P, Tomás-Pejó E, Ballesteros M and Negro M (2010), Pretreatment technologies for an efficient bioethanol production process based on enzymatic hydrolysis: a review, Bioresource technology 101(13): 4851-4861. DOI:org/10.1016/j.biortech.2009.11.093

Balat M, Balat $\mathrm{H}$ and Öz C (2008), Progress in bioethanol processing, Progress in energy and combustion science 34(5): 551-573. DOI:org/10.1016/j.pecs.2007.11.001

Chan E, Rudravaram R, Narasu ML, Rao LV and Ravindra $P$ (2007), Economics and environmental impact of bioethanol production technologies: an appraisal, Biotechnology and Molecular Biology Reviews 2(1): 14-32.

Chen M, Zhao J and Xia L (2008), Enzymatic hydrolysis of maize straw polysaccharides for the production of reducing sugars, Carbohydrate Polymers 71(3): 411-415. DOI:org/10.1016/j.carbpol.2007.06.011

da Silva ASA, Inoue H, Endo T, Yano S and Bon EP (2010), Milling pretreatment of sugarcane bagasse and straw for enzymatic hydrolysis and ethanol fermentation, Bioresource technology 101(19): 7402-7409.

Duff SJ and WD Murray (1996), Bioconversion of forest products industry waste cellulosics to fuel ethanol: a review, Bioresource technology 55(1): 1-33.

Galbe M, Lidén G and Zacchi G (2005), Production of ethanol from biomass-Research in Sweden. 
Inoue H, Yano S, Endo T, Sakaki T and Sawayama S (2008), Combining hot-compressed water and ball milling pretreatments to improve the efficiency of the enzymatic hydrolysis of eucalyptus, Biotechnology for biofuels 1(1): 2. DOI:org/10.1186/1754-6834-1-2

Jamal MS, Sujan SMA, Miah MY, Banik SK, Ahmed SU and Feroza B (2011), Ball milling pretreatment of bagasse for ethanol production by enzymatic saccharification and fermentation, Bangladesh J. Sci. Ind. Res. 46(3): 353-358. DOI:org/10.3329/bjsir.v46i3.9042

Karki B, Maurer D, Kim TH and Jung S (2011), Comparison and optimization of enzymatic saccharification of soybean fibers recovered from aqueous extractions, Bioresource technology 102(2): 1228-1233.

Klein-Marcuschamer D, Oleskowicz-Popiel P, Simmons BA and HW Blanch (2012), The challenge of enzyme cost in the production of lignocellulosic biofuels, Biotechnology and bioengineering 109(4): 1083-1087.

Kuriyama H, Seiko Y, Murakami T, Kobayashi H and Sonoda Y (1985), continuous ethanol fermentation with cell recycling using floculating yeast, Journal of fermentation technology 63(2): 159-165.

Lin Y and Tanaka S (2006), Ethanol fermentation from biomass resources: current state and prospects, Applied microbiology and biotechnology 69(6): 627-642.

Lin Z, Huang H, Zhang H, Zhang L, Yan L and Chen J (2010), Ball milling pretreatment of corn stover for enhancing the efficiency of enzymatic hydrolysis, Applied biochemistry and biotechnology 162(7): 1872-1880.

Lynd LR (1996), Overview and evaluation of fuel ethanol from cellulosic biomass: technology, economics, the environment and policy, Annual review of energy and the environment 21(1): 403-465.

Mais U, Esteghlalian AR, Saddler JN and Mansfield SD (2002), Enhancing the enzymatic hydrolysis of cellulosic materials using simultaneous ball milling, Biotechnology for Fuels and Chemicals: Humana Press, Totowa NJ: 815-832.

Mussatto SI, G Dragone, M Fernandes, AM Milagres and IC Roberto (2008), The effect of agitation speed, enzyme loading and substrate concentration on enzymatic hydrolysis of cellulose from brewer's spent grain, Cellulose 15(5): 711.

Nabi M, Hoque S and Uddin M (2009), Prospect of Jatropha curcas and pithraj cultivation in Bangladesh, $J$ Eng Technol 7(1): 41-54.
Ong LG, CH Chan and AL Chew (2012), Enzymatic hydrolysis of rice straw: process optimization, Journal of Medical and Bioengineering (JOMB) 1(1).

Palmqvist E, Hahn-Hägerdal B, Galbe M, Larsson M, Stenberg K, Szengyel Z, C Tengborg C and Zacchi G (1996), Design and operation of a bench-scale process development unit for the production of ethanol from lignocellulosics, Bioresource Technology 58(2): 171-179. DOI:org/10.1016/S0960-8524(96)00096-X

Sanchez OJ and Cardona CA (2008), Trends in biotechnological production of fuel ethanol from different feedstocks, Bioresource technology 99(13): 5270-5295. DOI:org/10.1016/j.biortech.2007.11.013

Sassner P, Galbe M and Zacchi G (2006), Bioethanol production based on simultaneous saccharification and fermentation of steam-pretreated Salix at high dry-matter content, Enzyme and Microbial Technology 39(4): 756-762.

Singh R, Vyas D, Srivastava N and Narra M (2008), SPRERI experience on holistic approach to utilize all parts of Jatropha curcas fruit for energy, Renewable Energy 33(8): 1868-1873.

Sluiter A, Hames B, Ruiz R, Scarlata C, Sluiter J, Templeton D and D Crocker D (2008), Determination of structural carbohydrates and lignin in biomass, Laboratory analytical procedure 1617: 1-16.

Sun Y and J Cheng J (2002), Hydrolysis of lignocellulosic materials for ethanol production: a review, Bioresource Technology 83(1): 1-11. DOI:org/10.1016/ S0960-8524(01)00212-7

Taherzadeh MJ and Karimi K (2007), Enzymatic-based hydrolysis processes for ethanol from lignocellulosic materials: A review, BioResources 2(4): 707-738.

TeramotoY, Lee SH and Endo T (2008), Pretreatment of woody and herbaceous biomass for enzymatic saccharification using sulfuric acid-free ethanol cooking, Bioresource Technology 99(18): 8856-8863. DOI:org/10.1016/j.biortech.2008.04.049

Yang S, Ding W and Chen H (2006), Enzymatic hydrolysis of rice straw in a tubular reactor coupled with UF membrane, Process Biochemistry 41(3): 721-725. DOI:org/10.1016/j.procbio.2005.08.002

$\mathrm{Yu} \mathrm{Z}$ and Zhang $\mathrm{H}$ (2003), Ethanol fermentation of acid-hydrolyzed cellulosic pyrolysate with Saccharomyces cerevisiae, Bioresource Technology 90(1): 95-100. DOI: 10.1016/j.biortech.2003.09.016 